Murder Frames the Scene 



\section{Murder Frames the Scene}

A HAWAI'I MYSTERY

VICTORIA NALANI KNEUBUHL

A LATITUDE 20 BOOK 
(C) 2016 Victoria Nalani Kneubuhl

All rights reserved

Printed in the United States of America

$\begin{array}{llllllllllll}21 & 20 & 19 & 18 & 17 & 16 & 6 & 5 & 4 & 3 & 2 & 1\end{array}$

\section{Library of Congress Cataloging-in-Publication Data}

Names: Kneubuhl, Victoria N. (Victoria Nalani), author.

Title: Murder frames the scene : a Hawai' i mystery / Victoria Nalani Kneubuhl.

Description: Honolulu : University of Hawai'i Press, 2016. | "A latitude 20 book."

Identifiers: LCCN 2015038299 | ISBN 9780824855291 pbk. : alk. paper

Subjects: | LCGFT: Detective and mystery fiction

Classification: LCC PS3561.N418 M883 2016| DDC 813/.54-dc23

LC record available at http://lccn.loc.gov/2015038299

University of Hawai'i Press books are printed on acid-free paper and meet the guidelines for permanence and durability of the Council on Library Resources. 